\title{
Complement Membrane Attack Complex Stimulates Production of Reactive Oxygen Metabolites by Cultured Rat Mesangial Cells
}

\author{
S. Adler, P. J. Baker, R. J. Johnson, R. F. Ochi, P. Pritzl, and W. G. Couser \\ Division of Nephrology, Department of Medicine, University of Washington, Seattle, Washington 98195
}

\begin{abstract}
To explore possible mechanisms by which complement membrane attack complexes (MAC) that are deposited in the glomerular mesangium might be pathogenic, we stimulated rat glomerular mesangial cells grown in vitro with nascent MACs formed from the purified human complement components C5b6 and normal human serum and measured production of superoxide ion $\left(\mathrm{O}_{2}^{-}\right)$and hydrogen peroxide $\left(\mathrm{H}_{2} \mathrm{O}_{2}\right)$. Mesangial cells incubated with C5b6 + serum, which results in cell membrane interaction with the MAC, produce $0.9 \pm 0.15 \mathrm{nmol} \mathrm{O}_{2}^{-} / 10^{5}$ cells per $30 \mathrm{~min}$, which was significantly greater than the amount produced by cells incubated with $\mathrm{C} 5 \mathrm{b6}$ alone, serum alone, or decayed MACs that can no longer interact with the cell membrane $\left(0.3 \pm 0.2,0.4 \pm 0.1,0.3 \pm 0.2 \mathrm{nmol} \mathrm{O}_{2}^{-} / 10^{5}\right.$ cells per $30 \mathrm{~min}$, respectively; $P<0.02$ ). Production of $\mathrm{O}_{2}^{-}$after stimulation with MACs increased during the first $20 \mathrm{~min}$ of incubation but then plateaued. Cells exposed to decayed MACs produced small amounts of $\mathrm{O}_{2}^{-}$, which did not increase from 20 to $60 \mathrm{~min}$. Production of $\mathrm{H}_{2} \mathrm{O}_{2}$ was also observed after stimulation with MACs, and continued to increase during $60 \mathrm{~min}$ of incubation (1.22 \pm 0.16 nmol $\mathrm{H}_{2} \mathrm{O}_{2} / 10^{5}$ cells per $60 \mathrm{~min}$ ), whereas $\mathrm{H}_{2} \mathrm{O}_{2}$ production could not be detected after exposure to decayed MACs. Cell viability was not adversely affected by exposure to nascent MACs as determined by trypan blue exclusion or chromium-51 release. These results demonstrate that glomerular mesangial cell membrane interaction with the MAC stimulates the production of the toxic oxygen metabolites $\mathrm{O}_{2}^{-}$and $\mathrm{H}_{2} \mathrm{O}_{2}$. Activation of the terminal complement pathway by mesangial immune deposits in vivo might lead to tissue injury by stimulation of local production of toxic oxygen-free radicals.
\end{abstract}

\section{Introduction}

The complement system is well established as an important mediator of immune renal disease (1-3). Studies carried out primarily in models of antiglomerular basement-membrane

Portions of this work have been presented at the Annual Meeting of the American Federation for Clinical Research, May, 1985; and have been published in abstract form, 1985. Clin. Res. 33:474A.

Please address reprint requests to Dr. Adler, Division of Nephrology, Box RM-11, University of Washington, Seattle, WA 98195. 1985.

Received for publication 29 July 1985 and in revised form 17 October

J. Clin. Invest.

(C) The American Society for Clinical Investigation, Inc.

0021-9738/86/03/0762/06 \$1.00

Volume 77, March 1986, 762-767
$(G B M)^{1}$ antibody-induced glomerulonephritis have elucidated an indirect role for complement acting through chemotactic (C5a) or immune adherence (C3b) mechanisms to attract circulating inflammatory cells that have been shown to be the principal mediators of tissue injury and proteinuria in these models (2-5). We have documented an additive direct effect of complement in mediating proteinuria induced by the in situ formation of subepithelial immune complexes that involve both endogenous cell membrane and exogenous planted antigens (6, 7). In these models of experimental membranous nephropathy, there is no participation of inflammatory cells, and the pathogenic mechanism has been postulated to involve instead the assembly of the complement membrane attack complex (C5b9 [MAC] $(6,7)$. Support for this hypothesis has been derived from subsequent studies demonstrating a requirement for $\mathrm{C} 6$ in the production of glomerular injury in several models of immune glomerular disease (8-10). MAC neoantigens have also been demonstrated in glomeruli in various human and experimental glomerular diseases and appear to correlate with complementdependent glomerular injury in appropriately studied experimental models (11-22).

The mechanism by which the MAC produces glomerular injury is not known. Recent studies suggest that reactive oxygen metabolites (ROM) produced by activated neutrophils are important mediators of glomerular injury in several experimental diseases that are neutrophil-mediated (23-25). Moreover, it has recently been demonstrated that resident glomerular mesangial cells are also capable of producing ROM in response to certain stimuli $(26,27)$. This raises the possibility that resident glomerular cells may also participate in the mediation of some glomerular lesions. The MAC has recently been shown to be a potent stimulus to production of several potential inflammatory mediators by glomerular mesangial cells, including prostaglandins and an interleukin 1-like cytokine (28), and a similar effect of the MAC has been demonstrated in stimulating arachidonic acid metabolism in platelets and macrophages $(29,30)$. We therefore tested the hypothesis that the effect of the MAC in producing glomerular disease may involve a similar nonlethal activation of resident glomerular cells to produce ROM. Our findings demonstrate that sublethal quantities of the MAC are a potent stimulus to mesangial cell release of ROM, which may play a role in mediating glomerular lesions that are MAC-dependent.

1. Abbreviations used in this paper: GBM, glomerular basement membrane; GVB-EDTA, $4 \mathrm{mM}$ veronal buffered saline, $\mathrm{pH} 7.5$, with $0.1 \%$ gelatin and $10 \mathrm{mM}$ EDTA; HPO, horseradish peroxidase; KRPG, KrebsRinger phosphate buffer containing $0.5 \mathrm{mM} \mathrm{Ca}^{++}, 1.2 \mathrm{mM} \mathrm{Mg}^{++}, 0.1 \%$ glucose, pH 7.4; MAC(s), membrane attack complex(es); NHS, normal human serum; ROM, reactive oxygen metabolites; and SOD, superoxide dismutase. 


\section{Methods}

Mesangial cell culture. Glomeruli were isolated from the kidneys of male Sprague-Dawley rats weighing 100-150 g (Tyler Laboratories, Bellevue, WA) using stainless steel sieves, as described previously (31). After treatment with collagenase $(1,200 \mathrm{U} / \mathrm{ml}$; Cooper Biomedical, Malvern, PA) for $30 \mathrm{~min}$ at $37^{\circ} \mathrm{C}$, the glomeruli were plated on culture dishes in RPMI 1640 media containing $15 \%$ heat-inactivated fetal calf serum, penicillin $(100 \mathrm{U} / \mathrm{ml})$, streptomycin $(100 \mu \mathrm{g} / \mathrm{ml})$, amphotericin $(0.25 \mu \mathrm{g} / \mathrm{ml})$, and insulin $(0.66 \mathrm{U} / \mathrm{ml})$ (Irvine Scientific, Santa Ana, CA). Cultures were maintained at $37^{\circ} \mathrm{C}$ in $5 \% \mathrm{CO}_{2}$ in air and passaged every $7-10 \mathrm{~d}$ using trypsin-EDTA (Gibco Laboratories, Santa Clara, CA).

The initial outgrowth from glomeruli consisted of spindle- or stellateshaped cells as described by others (32). When these cells were passaged they exhibited other characteristics of mesangial cells, including contraction in response to $10^{-6} \mathrm{M}$ angiotensin II (33). Immunofluorescent staining of the cells was negative with antibody to Factor VIII (Atlantic Antibodies, Scarborough, ME). Intracellular fibrils of myosin and smooth muscle cell actin and the matrix components collagens type III and IV were demonstrated with monospecific antibodies (generous gifts of Drs. L. and G. Striker and A. Gown). Epithelial cell contamination was excluded by the absence of cells with morphologic characteristics of epithelial cells and the ability of the passaged cells to grow in media containing aminonucleoside of puromycin $(10 \mu \mathrm{g} / \mathrm{ml}$; ICM Pharmaceuticals, Cleveland, $\mathrm{OH})$ but not mitomycin C (10 $\mu \mathrm{g} / \mathrm{ml}$; Sigma Chemical Co., St. Louis, MO) (34). Macrophage contamination was excluded by the absence of immunofluorescent staining with antibody to rat common leukocyte antigen (Pel-Freez Biologicals, Rogers, AR), negative staining for nonspecific esterase (Sigma Chemical Co.) and the inability of the cells to ingest latex particles (Sigma Chemical Co.). Cells were used for experiments after the second or third passage.

Isolation and purification of C5b6. C5b6 was isolated according to the method of Yamamoto and Gewurz (35). Briefly, a 20\% sodium sulfate precipitate of fresh frozen normal human serum was applied to a column of DEAE-cellulose (Whatman Laboratory Products, Clifton, NJ) in 0.1 $\mathrm{M}$ phosphate buffer, $\mathrm{pH} 7.5$, conductance 7.0 millisiemens $/ \mathrm{cm}$ and eluted with a linear $\mathrm{NaCl}$ gradient in the same buffer $(7-25$ millisiemens $/ \mathrm{cm})$. Column fractions were assayed for $\mathrm{C} 5, \mathrm{C} 6$, and $\mathrm{C} 7$ hemolytic activity by conventional hemolytic assays (11). Zymosan (Sigma Chemical Co.) was activated by incubation in normal human serum $(4 \mathrm{mg} / \mathrm{ml})$ for 30 min at $37^{\circ} \mathrm{C}$. Fractions containing $\mathrm{C} 5$ and $\mathrm{C} 6$, but free of $\mathrm{C} 7$, were pooled and incubated with activated zymosan at $37^{\circ} \mathrm{C}$ for $60 \mathrm{~min}$ to form C5b6. After centrifugation to remove the zymosan, this pool was reapplied to a column of DEAE-cellulose in $0.01 \mathrm{M}$ phosphate buffer, pH 7.5, conductance $12 \mathrm{mmho} / \mathrm{cm}$, containing $25 \%$ glycerol, and the C5b6 was isolated by elution with a linear $\mathrm{NaCl}$ gradient in the same buffer $(12-28 \mathrm{mmho} / \mathrm{cm})$. The fractions containing $\mathrm{C} 5 \mathrm{~b} 6$ assayed as described below were pooled, concentrated, and chromatographed twice

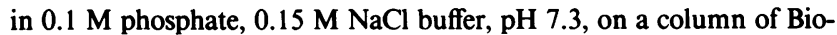
gel A $1.5 \mathrm{~m}$ (Bio-Rad Laboratories, Richmond, CA) for final purification. C5b6 was stored at $-70^{\circ} \mathrm{C}$ and dialyzed against Krebs-Ringer phosphate buffer (KRPG) containing $0.5 \mathrm{mM} \mathrm{Ca}^{++}, 1.2 \mathrm{mM} \mathrm{Mg}^{++}, 0.1 \%$ glucose, $\mathrm{pH} 7.4$, immediately before use in experiments.

C5b6 hemolytic activity was titered by combining equal volumes of dilutions of the sample, a suspension of guinea pig erythrocytes $(5$ $\times 10^{8}$ cells $/ \mathrm{ml}$ ) in $4 \mathrm{mM}$ veronal buffered saline, $\mathrm{pH} 7.5$, with $0.1 \%$ gelatin and 10 mM EDTA (GVB-EDTA), and a 1:20 dilution of human serum in the same buffer followed by incubation for $30 \mathrm{~min}$ at $37^{\circ} \mathrm{C}$. Absorbance of the supernatants was determined at $541 \mathrm{~nm}$ in a spectrophotometer and the percent lysis calculated by comparison with an equal number of cells lysed in distilled water. The dilution giving $50 \%$ lysis was calculated from a linear regression plot of -In (1-\%lysis) vs. sample dilution. The reciprocal of this value is the number of hemolytic complement units per milliliter.

Experimental design. To produce MACs capable of interacting with the mesangial cell membrane, we used the stable complement intermediate C5b6. This complex can associate with cell membranes and in the presence of a source of the other terminal complement components will result in assembly and membrane binding of the MAC (36-38). If C5b6 is allowed to react with serum in the absence of cells, a decayed MAC is formed that can no longer bind to cell membranes $(37,38)$

In initial experiments to evaluate ROM production by mesangial cells in response to MAC, we removed cells from culture plates with 0.6 mM EDTA, washed twice with KRPG, aliquoted into individual tubes ( $10^{5}$ cells per tube), and assayed $\mathrm{O}_{2}^{-}$production as described below after the addition of the MAC and control stimuli to cells. MAC formation in the presence of mesangial cells was initiated by addition to the cell suspension of $\mathrm{C} 5 \mathrm{~b} 6$ ( $17 \mathrm{U} / \mathrm{ml}$ final concentration) followed by fresh normal human serum (NHS) diluted 1:20 with KRPG containing $10 \mathrm{mM}$ EDTA. Decayed MACs, which do not bind to cell membranes, were formed by incubating the $\mathrm{C} 5 \mathrm{~b} 6$ and NHS together for $15 \mathrm{~min}$ at $37^{\circ} \mathrm{C}$ before addition to the cells. Other controls included cells incubated with similar final concentrations of $\mathrm{C} 5 \mathrm{~b} 6$ alone, or NHS alone. Reagents for the assay of $\mathrm{O}_{2}^{-}$production, described below, were immediately added and all tubes incubated for $30 \mathrm{~min}$ at $37^{\circ} \mathrm{C}$. All reactions were run in duplicate or triplicate. The reaction was stopped by putting the tubes on ice and separating the supernatants by centrifugation at $4^{\circ} \mathrm{C}$. Absorbance was measured at $550 \mathrm{~nm}$, the amount of cytochrome $\mathrm{c}$ reduced was calculated as described below and then converted to nanomoles $\mathrm{O}_{2}^{-}$produced $/ 10^{5}$ cells per $30 \mathrm{~min}$.

In later experiments, we added reagents directly to the culture plates. Cells were stimulated with MACs by addition of C5b6 $(14 \mathrm{U} / \mathrm{ml}$ final concentration) and NHS (1:20) or with the same amount of decayed complexes. Reagents for the assay of $\mathrm{O}_{2}^{-}$or $\mathrm{H}_{2} \mathrm{O}_{2}$ production, described below, were immediately added, and the plates were incubated in duplicate or triplicate for $10,20,30$, or 60 min at $37^{\circ} \mathrm{C}$ in $5 \% \mathrm{CO}_{2}$ in air. Supernatants were removed and $\mathrm{O}_{2}^{-}$or $\mathrm{H}_{2} \mathrm{O}_{2}$ release measured as described below. All cells were removed from culture plates with trypsinEDTA (Gibco Laboratories), counted in a hemocytometer, and the results expressed as nanomoles $\mathrm{O}_{2}^{-}$or $\mathrm{H}_{2} \mathrm{O}_{2}$ produced $/ 10^{5}$ cells per unit of time.

Cell viability after exposure to the concentration of complement components and serum used in these experiments was assessed by trypan blue exclusion and by chromium-51 $\left(\mathrm{Cr}^{51}\right)$ release. Cells in culture plates were incubated with KRPG alone, C5b6 plus NHS, or decayed complexes for $30 \mathrm{~min}$ at $37^{\circ} \mathrm{C}$ in $5 \% \mathrm{CO}_{2}$ in air. Trypan blue exclusion was determined on cells removed with trypsin-EDTA after mixing with an equal volume of $0.1 \%$ trypan blue (Gibco Laboratories). $\mathrm{Cr}^{31}$ release was determined on cells previously incubated overnight with $0.5 \mathrm{mCi}$ of $\mathrm{Cr}^{51}$ (New England Nuclear, Boston, MA) and washed twice with KRPG buffer before addition of buffer or complement and serum. Cell supernatants and cells solubilized in 1\% Triton X-100 (Sigma Chemical Co.) were counted in a gamma counter (Packard Instrument Co., Downers Grove, IL) and the percent $\mathrm{Cr}^{51}$ release calculated from counts in supernatant/(counts in supernatant + counts in cells).

Measurement of ROM production. Production of superoxide ion $\left(\mathrm{O}_{2}^{-}\right)$was measured as the superoxide dismutase (SOD) inhibitable reduction of cytochrome $c$ as described by others (39). Mesangial cells plus the desired stimulus were incubated in KRPG buffer containing a final concentration of $80 \mu \mathrm{M}$ cytochrome c, with or without SOD $(40 \mu \mathrm{g} / \mathrm{ml}$; Sigma Chemical Co.). Incubations were carried out for various periods up to $1 \mathrm{~h}$ at $37^{\circ} \mathrm{C}$ in $5 \% \mathrm{CO}_{2}$ in air as outlined above. Reactions were run in duplicate or triplicate. The amount of cytochrome $\mathrm{c}$ reduced was determined from the difference between the absorption of the supernatants with and without SOD at $550 \mathrm{~nm}$, using the extinction coefficient $\mathrm{E}_{550}=2.1 \times 10^{4} / \mathrm{M}$ per $\mathrm{cm}$.

Production of hydrogen peroxide $\left(\mathrm{H}_{2} \mathrm{O}_{2}\right)$ was measured by its ability to oxidize the fluorescent compound scopoletin to its nonfluorescent form in the presence of horseradish peroxidase (HPO; Sigma Chemical Co.) (40). Mesangial cells plus the desired stimulus were incubated in KRPG buffer containing a final concentration of $2 \mu \mathrm{M}$ scopoletin and $0.1 \mathrm{mg} / \mathrm{ml} \mathrm{HPO}$. Incubations were carried out for various periods up to $1 \mathrm{~h}$ at $37^{\circ} \mathrm{C}$ in $5 \% \mathrm{CO}_{2}$ in air. Reactions were run in duplicate or triplicate. The decrease in fluorescence compared with a reagent blank at $460 \mathrm{~nm}$ with excitation at $350 \mathrm{~nm}$ was measured in a spectrophotofluorometer (American Instrument Co., Silver Springs, MD) and compared with a standard curve obtained with known amounts of $\mathrm{H}_{2} \mathrm{O}_{2}$. 
Analysis of data. All values are expressed as mean \pm SEM. Results of cell viability studies and levels of production of oxygen metabolites were compared with controls and each other using Student's $t$ test (41) applying a correction for multiple comparisons when appropriate (42). $P$ values $<0.05$ were regarded as significant.

\section{Results}

Cell viability. After exposure to C5b6 plus serum for $30 \mathrm{~min}$, a process that results in the active production of MACs, $80.2 \pm 6.8 \%$ ( $n=$ four culture plates) of mesangial cells excluded trypan blue. This was not significantly different from cells exposed to buffer alone $(78.5 \pm 3.6 \%, n=8, P>0.20)$ or to decayed C5b-9 complexes incapable of cell membrane insertion $(77.4 \pm 4.5 \%, n=4$, $P>0.20$ ). Similarly, cells exposed to MACs released only $3.8 \pm 0.2 \%(n=3)$ of the $\mathrm{Cr}^{51}$ label after $30 \mathrm{~min}$, which was not significantly different from cells exposed to buffer alone (3.2 $\pm 0.2 \%, n=6, P>0.10)$ or to decayed complexes $(6.3 \pm 1.8 \%$, $n=3, P>0.20)$. These results demonstrate that C5b6 in the concentrations used did not induce cell lysis or adversely affect cell viability.

Production of $\mathrm{O}_{2}^{-}$by mesangial cells. In initial experiments, mesangial cells were removed from culture plates and incubations were carried out with cells in suspension. Mesangial cells incubated with serum alone or decayed complexes, which do not interact with cell membranes, produced small amounts of $\mathrm{O}_{2}^{-}\left(0.4 \pm 0.1\right.$ and $0.3 \pm 0.2 \mathrm{nmol} \mathrm{O}_{2}^{-} / 10^{5}$ cells, respectively; Fig. 1) during the 30 -min incubation period that were not significantly different from cells incubated with buffer alone $(0.08 \pm 0.03 \mathrm{nmol}$ $\mathrm{O}_{2}^{-} / 10^{5}$ cells, $n=6, P>0.05$, data not shown). Cells incubated with $\mathrm{C} 5 \mathrm{~b} 6$ alone produced small amounts of $\mathrm{O}_{2}^{-}$that just reached significance when compared with cells incubated with buffer alone $\left(0.3 \pm 0.2 \mathrm{nmol} \mathrm{O}_{2}^{-} / 10^{5}\right.$ cells, $\left.P<0.05\right)$. When cells were incubated with $\mathrm{C} 5 \mathrm{~b} 6$ + serum, resulting in cell membrane exposure to actively forming MACs, $0.9 \pm 0.15 \mathrm{nmol} \mathrm{O}-1 / 10^{5}$ cells were produced during the 30 -min incubation ( $n=7$ experiments, Fig. 1). The amount of $\mathrm{O}_{2}^{-}$produced by MAC-stimulated cells was significantly greater than that produced during incubation with C5b6, serum, or decayed complexes $(P<0.02)$.

For subsequent experiments, reagents were added directly

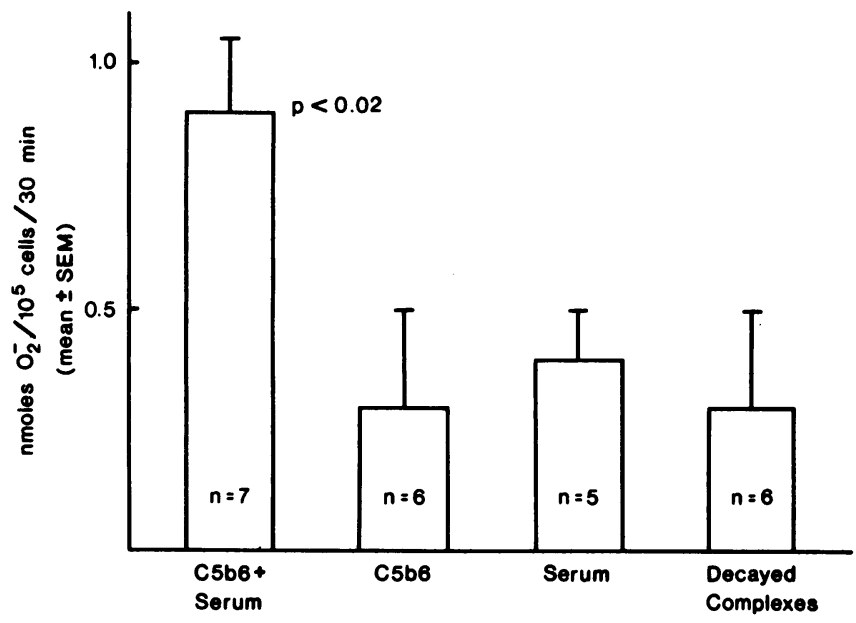

Figure 1. Superoxide ion production by cultured rat mesangial cells. Cells were incubated for $30 \mathrm{~min}$ in suspension with stimuli and cytochrome $\mathrm{c}$ and production of $\mathrm{O}_{2}^{-}$was measured. Cells incubated with $\mathrm{C5b6}+$ serum, which results in active MAC formation, produced significantly more $\mathrm{O}_{2}^{-}$than the three controls $(P<0.02 ; n$, number of experiments). to cells in culture plates. To assess the time course of $\mathrm{O}_{2}^{-}$production by mesangial cells in response to the MAC, cells were incubated with C5b6 + serum or with decayed complexes and production of $\mathrm{O}_{2}^{-}$was measured in duplicate or triplicate samples after different periods of incubation up to $1 \mathrm{~h}$ (Fig. 2). Stimulation of cells with $\mathrm{C} 5 \mathrm{~b} 6+$ serum resulted in significantly greater production of $\mathrm{O}_{2}^{-}$when compared with cells incubated with decayed complexes at all times studied $(P<0.05)$. Production of $\mathrm{O}_{2}^{-}$ increased during the first $20 \mathrm{~min}$ of observation, but then plateaued with a small but insignificant increase between 20 and $60 \mathrm{~min}\left(1.8 \pm 0.5\right.$ and $2.5 \pm 0.5 \mathrm{nmol} \mathrm{O}_{2}^{-} / 10^{5}$ cells, respectively; $P>0.20)$. Cells incubated with decayed complexes produced small amounts of $\mathrm{O}_{2}^{-}$that did not increase significantly from 20 to $60 \mathrm{~min}(P>0.10)$.

Production of $\mathrm{H}_{2} \mathrm{O}_{2}$ by mesangial cells. Production of $\mathrm{H}_{2} \mathrm{O}_{2}$ by mesangial cells stimulated with $\mathrm{C} 5 \mathrm{~b} 6+$ serum (Fig. 3) could be detected as early as $10 \mathrm{~min}$ but did not become significant until $20 \mathrm{~min}\left(0.68 \pm 0.08 \mathrm{nmol} \mathrm{H}_{2} \mathrm{O}_{2} / 10^{5}\right.$ cells, $\left.P<0.02\right) . \mathrm{H}_{2} \mathrm{O}_{2}$ production continued to increase up to $1 \mathrm{~h}$ of incubation $\left(1.22 \pm 0.16 \mathrm{nmol} \mathrm{H}_{2} \mathrm{O}_{2} / 10^{5}\right.$ cells) although the increase did not achieve significance $(P>0.05)$. Incubation of mesangial cells with decayed complexes did not result in measurable production of $\mathrm{H}_{2} \mathrm{O}_{2}$.

\section{Discussion}

The importance of the C5b-9, or membrane attack portion, of the complement pathway as a direct mediator of glomerular injury has recently been established (43). A role for the MAC in glomerular injury was first suggested by the observation that proteinuria in experimental models of membranous nephropathy induced by in situ immune complex formation, involving both fixed and planted subepithelial antigens, was complement-dependent but inflammatory cell-independent $(6,7)$. Clarification for this hypothesis derived from studies of animals genetically deficient in or depleted of $\mathrm{C} 6(8-10)$. Thus, in rabbits with chronic serum sickness induced by repeated injections of cationized bovine serum albumin, proteinuria is reduced in C6deficient rabbits (8). The same is true in rabbits with nephritis induced by deposition of anti-GBM antibody (9). Finally, in the passive Heymann model of experimental membranous nephropathy in rats, depletion of C6 totally prevents the devel-

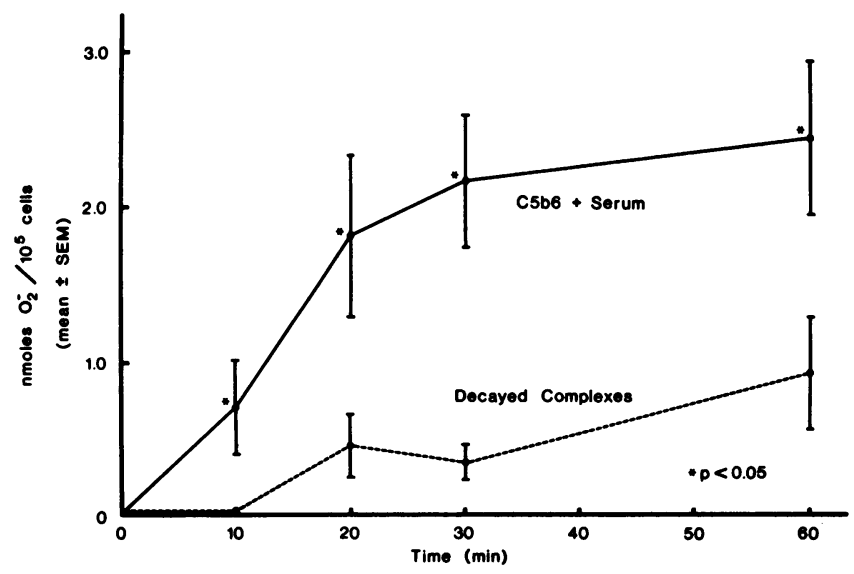

Figure 2. Superoxide ion production by cultured rat mesangial cells. Cells in culture plates were incubated with cytochrome $\mathrm{c}$ and C5b6 + serum or decayed complexes. C5b6 + serum-stimulated cells produced significantly more $\mathrm{O}_{2}^{-}$than cells incubated with decayed complexes at all times studied $(P<0.05)$. Each point represents mean \pm SEM of 5 experiments. 


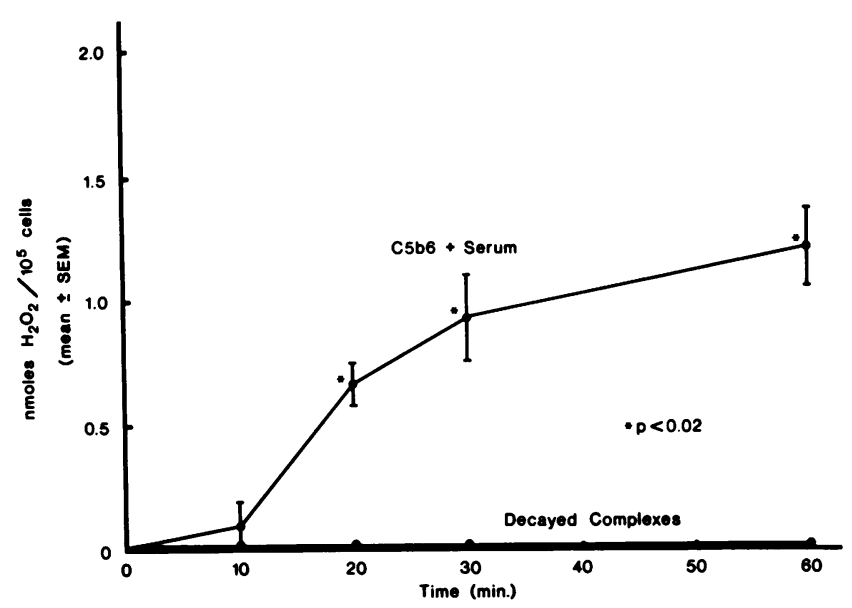

Figure 3. $\mathrm{H}_{2} \mathrm{O}_{2}$ production by cultured rat mesangial cells. Cells in culture plates were incubated with horseradish peroxidase, scopoletin, and $\mathrm{C} 5 \mathrm{~b} 6+$ serum or decayed complexes. C5b6 + serum-stimulated cells produced significant amounts of $\mathrm{H}_{2} \mathrm{O}_{2}$ after $20 \mathrm{~min}(P<0.02)$. Cells incubated with decayed complexes did not produce detectable $\mathrm{H}_{2} \mathrm{O}_{2}$. Each point represents mean \pm SEM of five experiments.

opment of proteinuria (10). Thus, clear evidence exists for an important functional role of the MAC in mediating several forms of antibody-induced glomerular disease. However, the mechanism of this effect remains unclear. Since circulating inflammatory cells are not involved in several of these MAC-dependent lesions, the possibility of a pathogenic effect of C $5 \mathrm{~b}-9$ on resident glomerular cells was explored in this study.

Our results demonstrate for the first time that the MAC, in quantities that are not cytotoxic, can act as a membrane stimulus for the production of reactive oxygen metabolites (ROM). Assembly of the MAC in these studies was initiated by the addition of C5b6 plus fresh serum to glomerular mesangial cells. The stable C5b6 complex is normally formed from the combination of $\mathrm{C} 6$ with $\mathrm{C} 5 \mathrm{~b}$ produced by the spontaneous cleavage of $\mathrm{C} 5$ $(37,38)$. Binding of $\mathrm{C} 7$ to $\mathrm{C} 5 \mathrm{~b} 6$ produces an amphiphilic complex, C5b-7, which can insert into the lipid bilayers of cell membranes, bind $\mathrm{C} 8$ and $\mathrm{C} 9$, and thereby lead to assembly of the MAC $(38,44)$. This process results in the lysis of antibody-coated erythrocytes, but nucleated cells are more resistant to lysis (36) and some possess a mechanism for rapidly eliminating MACs from their surfaces (45). In our studies, MAC stimulation of cells was achieved by allowing C $5 \mathrm{~b}-9$ to form in the presence of viable mesangial cells. In the absence of cell membranes, but in the presence of serum, the $\mathrm{C} 5 \mathrm{~b}-7$ complex binds $\mathrm{C} 8, \mathrm{C} 9$, and a serum protein, the $\mathrm{S}$-protein, resulting in formation of a soluble decayed MAC that has no affinity for membranes or hemolytic activity $(44,46)$. We used these decayed complexes as controls and prepared them by incubating $\mathrm{C} 5 \mathrm{~b} 6$ plus serum before addition of this stimulus to mesangial cells.

When cultured mesangial cells were exposed to actively forming MACs, significant production of both $\mathrm{O}_{2}^{-}$and $\mathrm{H}_{2} \mathrm{O}_{2}$ occurred. In contrast, exposure to decayed complexes did not stimulate significant production of $\mathrm{H}_{2} \mathrm{O}_{2}$ or $\mathrm{O}_{2}^{-}$compared with unstimulated cells. This suggests that membrane interaction of the MAC is required in the process of stimulating the cellular production of ROM. Cells incubated with C5b6 or serum alone produced small amounts of $\mathrm{O}_{2}^{-}$that were only marginally significant or not different when compared with controls. When cells were stimulated directly in the culture plates on which they had been growing, the amounts of $\mathrm{O}_{2}^{-}$produced in response to
MACs were always greater than that seen with cells studied in suspension, although the response to decayed MACs was similar under both conditions. This observation, which may reflect some loss of $\mathrm{O}_{2}^{-}$producing capacity during removal from the culture plates, prompted us to perform all subsequent experiments on undisturbed cells.

The suggestion that production of ROM by glomerular mesangial cells may be of pathogenic significance is supported by comparisons of the quantities of ROM produced by these cells with those produced by phagocytic leukocytes that are known to induce ROM-mediated glomerular injury. We found that mesangial cells produced $\sim 28-68 \mathrm{nmol} \mathrm{O}_{2}^{-}$and $\sim 30 \mathrm{nmol}$ $\mathrm{H}_{2} \mathrm{O}_{2} / \mathrm{mg}$ cell protein per 30 min (based on $\sim 30 \mu \mathrm{g}$ protein $/ 10^{5}$ cells) when stimulated by MAC. These quantities are comparable to the 3-172 $\mathrm{nmol} \mathrm{O}_{2}^{-}$and 7.3-438 $\mathrm{nmol} \mathrm{H}_{2} \mathrm{O}_{2} / \mathrm{mg}$ protein per 30 min produced by macrophages from several species exposed to various particulate and soluble stimuli (47). The amounts of $\mathrm{O}_{2}^{-}$and $\mathrm{H}_{2} \mathrm{O}_{2}$ production by stimulated mesangial cells in our studies are also comparable to levels of production by stimulated neutrophils that have been reported in the range of $0.3-2.3 \mathrm{nmol}$ $\mathrm{O}_{2}^{-}$and $0.14-0.75 \mathrm{nmol} \mathrm{H}_{2} \mathrm{O}_{2} / 10^{5}$ cells per $15 \mathrm{~min}$ (47). The time course of $\mathrm{O}_{2}^{-}$and $\mathrm{H}_{2} \mathrm{O}_{2}$ production we observed in MACstimulated mesangial cells is similar to that reported by Baud et al. (26) for mesangial cells stimulated with opsonized zymosan, although the overall levels produced were slightly lower. These findings extend the observations of Lovett et al. (28) who have shown MAC to be a stimulus for release of prostaglandin $E_{2}$, thromboxane, and an interleukin 1-like growth factor by rat mesangial cells. A similar effect of exposure to C5b-9 on arachidonic acid metabolism has been reported with platelets, macrophages, and tumor cells in vitro $(29,30,48)$.

ROM are important mediators of tissue damage (reviewed in references $47,49,50$ ). Their importance in the production of renal injury has only recently been appreciated. In ischemic acute renal failure in the rat, administration of $\mathrm{SOD}$, an $\mathrm{O}_{2}^{-}$ scavenger, or dimethylthiourea, a hydroxyl radical scavenger, improves renal function after reperfusion as does the xanthine oxidase inhibitor allopurinol (51). In three models of neutrophildependent proteinuria, produced by intra-renal infusion of cobra venom factor, anti-GBM antibody, or phorbol myristate acetate (a potent stimulator of ROM production by phagocytic leukocytes), both histologic injury and proteinuria were reduced by administration of catalase that catalyses the conversion of $\mathrm{H}_{2} \mathrm{O}_{2}$ to oxygen and water (23-25). Several mechanisms by which ROM may contribute to tissue injury have been identified that may be important in the production of renal injury. Endothelial cell damage in models of pulmonary injury and immune complex-induced vasculitis appears to involve production of $\mathrm{H}_{2} \mathrm{O}_{2}$ and hydroxyl radicals by infiltrating leukocytes (52-54). Interaction of ROM with serum or arachidonic acid also leads to production of chemotactic lipids that may cause further accumulation of inflammatory cells $(55,56)$. ROM may enhance tissue injury due to proteases released by infiltrating cells by inactivating antiproteases such as alpha-1-antitrypsin $(57,58)$. Paradoxically, they may also participate in the activation of proteases, as evidenced by the recent demonstration that hypochlorous acid generated in neutrophils from $\mathrm{H}_{2} \mathrm{O}_{2}$ and chloride by myeloperoxidase is important in the activation of a latent collagenase present in these cells (59). The myeloperoxidase- $\mathrm{H}_{2} \mathrm{O}_{2}$ halide system can also lead to halogenation of proteins, an important mechanism of microbial killing by phagocytes that we have recently demonstrated to also be capable of producing glomerular injury in rats (60). Studies of the interactions of $\mathrm{O}_{2}^{-}$and 
other ROM with joint components have demonstrated their ability to degrade hyaluronic acid (a glycosaminoglycan) in synovial fluid and proteoglycans and collagen in cartilage (61-63). Furthermore, exposure of cultured cartilage to an $\mathrm{O}_{2}^{-}$generating system inhibited synthesis of proteoglycans (64), and exposure of GBM and fibronectin to $\mathrm{H}_{2} \mathrm{O}_{2}$ was shown to enhance their susceptibility to proteolysis (65).

With regard to the possible pathogenic significance of MAC stimulation of mesangial cells in human renal disease, small deposits of MAC neoantigens, usually in the absence of immunoglobulins and $\mathrm{C} 3$, are found in the mesangium in a wide variety of lesions, many of which are not generally considered to be of immunologic origin, and are also seen in sclerotic areas as well as in normal kidneys (16-20). The frequent association of MAC deposits with cell membrane fragments (20) and the capacity of damaged cells to activate complement (66) suggest that the MACs may form locally in the glomerulus rather than being trapped from the circulation. Whether the MAC is pathogenic in the absence of immune deposits is unclear, but the ability of MAC without immune complexes to stimulate production of ROM and other inflammatory mediators by mesangial cells, as described above, might contribute to local injury.

Of particular interest with regard to our studies are the mesangial MAC deposits associated with IgG and C3 in several immune-mediated renal diseases, including lupus (sytemic lupus erythematosus) nephritis, types I and II membrano-proliferative glomerulonephritis, IgA nephropathy, Henoch-Schonlein purpura, and poststreptococcal nephritis (16-22). In all these lesions, cellular proliferation and mesangial matrix expansion are typical morphologic findings. These morphologic abnormalities may be linked to the production of inflammatory mediators such as ROM by either endogenous glomerular cells or by infiltrating cells stimulated by exposure to the MAC.

In summary, exposure of rat glomerular mesangial cells in culture to MAC stimulates the production of the reactive oxygen metabolites $\mathrm{O}_{2}^{-}$and $\mathrm{H}_{2} \mathrm{O}_{2}$. These highly reactive molecules are known to contribute to glomerular injury induced by circulating inflammatory cells and may therefore be pathogenic when released locally by resident glomerular cells. The common finding of MAC neoantigen localization in the mesangium in many human and experimental renal diseases is consistent with the suggestion that a similar phenomena may occur in vivo and could contribute to the production of glomerular injury through any of the mechanisms outlined above. These studies, therefore, define a new mechanism that may relate to the established pathogenic role of the terminal complement pathway in mediating several forms of immune glomerular disease.

\section{Acknowledgments}

The authors wish to thank Mrs. R. Park for expert technical assistance and Ms. M. Whitcomb, C. Berget, and B. Tai for assistance in preparation of the manuscript.

Support for this work was provided by research grants AM17722, AM32051, AM32082, and by training grant AM07467 from the United States Public Health Service, and by grants to Dr. Adler and Dr. Baker from the Northwest Kidney Foundation.

\section{References}

1. Cochrane, C. G., H. J. Muller-Eberhard, and B. S. Aikin. 1970. Depletion of plasma complement in vivo by a protein of cobra venom: its effect on various immunologic reactions. J. Immunol. 105:55-69.
2. Couser, W. G., and D. J. Salant. 1982. Immunopathogenesis of glomerular capillary wall injury in nephrotoxic states. Contemp. Issues Nephrol. 9:47-83.

3. Schreiber, R. D., and H. J. Muller-Eberhard. 1979. Complement and renal disease. Contemp. Issues Nephrol. 3:67-105.

4. Cochrane, C. J., E. R. Unanue, and F. J. Dixon. 1965. A role of polymorphonuclear leukocytes and complement in nephrotoxic nephritis. J. Exp. Med. 122:99-116.

5. Unanue, E., and F. J. Dixon. 1964. Experimental glomerulonephritis. IV. Participation of complement in nephrotoxic nephritis. $J$. Exp. Med. 119:965-982.

6. Salant, D. J., S. Belok, M. P. Madaio, and W. G. Couser. 1980. A new role for complement in experimental membranous nephropathy in rats. J. Clin. Invest. 66:1339-1350.

7. Adler, S., D. J. Salant, J. E. Dittmer, H. G. Rennke, and M. P. Madaio. 1983. Mediation of proteinuria in membranous nephropathy due to a planted glomerular antigen. Kidney Int. 23:807-815.

8. Groggel, G. C., S. Adler, H. G. Rennke, W. G. Couser, and D. J. Salant. 1983. Role of the terminal complement pathway in experimental membranous nephropathy in the rabbit. J. Clin. Invest. 72:1948-1957.

9. Groggel, G. C., D. J. Salant, C. Darby, H. G. Rennke, and W. G. Couser. 1985. Role of the terminal complement pathway in the heterologous phase of anti-glomerular basement membrane nephritis in the rabbit. Kidney Int. 27:643-651.

10. Baker, P. J., R. Ochi, S. Adler, R. J. Johnson, and W. G. Couser. 1985. C6 depletion abolishes proteinuria in experimental membranous nephropathy. Clin. Res. 33:475A. (Abstr.)

11. Adler, S., P. J. Baker, P. Pritzl, and W. G. Couser. 1984. Detection of terminal complement components in experimental immune glomerular injury. Kidney Int. 26:830-837.

12. Perkinson, D. T., P. J. Baker, W. G. Couser, R. J. Johnson, and S. Adler. 1985. Membrane attack complex deposition in experimental glomerular injury. Am. J. Pathol. 120:121-128.

13. Biesecker, G., B. Noble, G. A. Andres, and D. Koffler. 1984. Immunopathogenesis of Heymann's nephritis. Clin. Immunol. Immunopathol. 33:333-338.

14. de Heer, E., M. R. Daha, S. Bhakdi, H. Bazin, and L. A. van Es. 1985. Possible involvement of terminal complement complex in active Heymann nephritis. Kidney Int. 22:388-393.

15. Koffler, D., G. Biesecker, B. Noble, G. A. Andres, and A. Martinez-Hernandez. 1983. Localization of the membrane attack complex (MAC) in experimental immune complex glomerulonephritis. J. Exp. Med. 157:1885-1905.

16. Falk, R. J., A. P. Dalmasso, Y. Kim, C. H. Tsai, J. I. Scheinman, H. Gewurz, and A. F. Michael. 1983. Neoantigen of the polymerized ninth component of complement. Characterization of a monoclonal antibody and immunohistochemicaí localization in renal disease. J. Clin. Invest. 72:560-573.

17. Rauterberg, E. W., T. Gehrig, and M. Lieberknecht. 1982. C59 neoantigen detection indicates a complete complement activation in various types of glomerulonephritis. Mol. Immunol. 19:1398. (Abstr.)

18. Adler, S., L. Striker, G. Striker, D. T. Perkinson, J. Hibbert, and W. G. Couser. 1985. Mechanisms of progressive glomulerar sclerosis in the rat. Kidney Int. 27:204. (Abstr.)

19. Kazatchkine, M. D., S. Bhakdi, N. Hinglais, and J. Bariety. 1983. Presence of the terminal C $5 \mathrm{~b}-9$ complement complex in distal arteries of normal and diseased human kidneys. Immunobiology. 164:262. (Abstr.)

20. Hinglais, N., M. D. Kazatchkine, S. Bhakdi, C. Mandet, and J. Bariety. 1984. Localization of the terminal C5b-9 complex of complement on cell remnants in connective matrices of human kidney. Abstr. Ninth Int. Congr. Nephrol. 242A.

21. Biesecker, G., S. Katz, and D. Koffler. 1981. Renal localization of the membrane attack complex in systemic lupus erythematosus nephritis. J. Exp. Med. 154:1779-1794.

22. Parra, G., J. L. Platt, R. J. Falk, B. Rodriquez-Iturbe, and A. F. Michael. 1984. Cell populations and membrane attack complex in glomeruli of patients with post-streptococcal glomerulonephritis. Identif- 
cation using monoclonal antibodies by indirect immunofluorescence. Clin. Immunol. Immunopathol. 33:324-332.

23. Rehan, A., K. J. Johnson, R. C. Wiggins, R. G. Kunkel, and P. A. Ward. 1984. Evidence for the role of oxygen radicals in acute nephrotoxic nephritis. Lab. Invest. 51:396-403.

24. Rehan, A., K. J. Johnson, R. G. Kunkel, and R. C. Wiggins. 1985. Role of oxygen radicals in phorbol myristate acetate induced glomerular injury. Kidney Int. 27:503-511.

25. Rehan, A., K. J. Johnson, R. C. Wiggins, and P. A. Ward. 1985. Oxygen free radical induced glomerular injury following intravascular activation of complements. Fed. Proc. 44:1546. (Abstr.)

26. Baud, L., J. Hagege, J. Sraer, E. Rondeau, J. Perez, and R. Ardaillou. 1983. Reactive oxygen production by cultured rat glomerular mesangial cells during phagocytosis is associated with stimulation of lipoxygenase activity. J. Exp. Med. 158:1836-1852.

27. Sedor, J. R., and H. E. Abboud. 1985. Platelet activating factor stimulates oxygen radical release by cultured rat mesangial cells. Kidney Int. 27:222. (Abstr.)

28. Lovett, D., G. Hansch, K. Resch, and D. Gemsa. 1984. Activation of glomerular mesangial cells by terminal complement components. Stimulation of prostanoid and interleukin I-like factor release. Immunobiology. 168:34-35. (Abstr.)

29. Polley, M. J., R. L. Nachman, and B. B. Weksler. 1981. Human complement in the arachidonic acid transformation pathway in platelets. J. Exp. Med. 153:257-268.

30. Hansch, G. M., M. Seitz, G. Marinotti, M. Betz, E. W. Rauterberg, and D. Gemsa. 1984. Macrophages release arachidonic acid, prostaglan$\operatorname{din} \mathrm{E}_{2}$, and thromboxane in response to late complement components. J. Immunol. 133:2145-2150.

31. Salant, D. J., C. Darby, and W. G. Couser. 1980. Experimental membranous glomerulonephritis in rats. Quantitative studies of glomerular immune deposit formation in isolated glomeruli and whole animals. J. Clin. Invest. 66:71-81.

32. Foidart, J. B., C. A. Dechenne, P. Mahieu, C. E. Crentz, and J. De Mey. 1979. Tissue culture of normal rat glomeruli. Invest. Cell Pathol. 2:15-26.

33. Ausiello, D. A., J. I. Kreisberg, C. Roy, and M. J. Karnovsky. 1980. Contraction of cultured rat glomerular cells of apparent mesangial origin after stimulation with angiotensin II and arginine vasopressin. $J$. Clin. Invest. 65:754-760.

34. Kreisberg, J. I., and M. J. Karnovsky. 1983. Glomerular cells in culture. Kidney Int. 23:439-447.

35. Yamamato, K. I., and H. Gewurz. 1978. The complex of C5b and C6: isolution, characterization and identification of a modified form of C5b consisting of three polypeptide chains. J. Immunol. 120:20082015.

36. Mayer, M. M., D. W. Michaels, L. E. Ramm, M. B. Whitlow, J. B. Willoughby, and M. L. Shin. 1981. Membrane damage by complement. Crit. Rev. Immunol. 7:133-165.

37. Biesecker, G. 1983. Membrane attack complex of complement as a pathologic mediator. Lab. Invest. 49:237-249.

38. Podack, E. R., and J. Tschopp. 1984. Membrane attack by complement. Mol. Immunol. 21:589-603.

39. Babior, B. M., R. S. Kipnes, and J. T. Curnutte. 1973. Biological defense mechanisms. The production by leukocytes of superoxide, a potential bactericidal agent. J. Clin. Invest. 52:741-744.

40. Root, R. K., J. Metcalf, N. Oshino, and B. Chance. 1975. $\mathrm{H}_{2} \mathrm{O}_{2}$ release from human granulocytes during phagocytosis. J. Clin. Invest. 55:945-955.

41. Snedecor, G. W., and W. G. Cochrane. 1967. Statistical Methods. The lowa State University Press, Ames, Ia. 91-119.

42. Wallenstein, S., C. L. Zucker, and J. L. Fleiss. 1980. Some statistical methods useful in circulation research. Circ. Res. 47:1-9.

43. Couser, W. G., P. J. Baker, and S. Adler. 1985. Complement and the direct mediation of immune glomerular injury. A new perspective. Kidney Int. In press.

44. Podack, E. R., G. Biesecker, W. P. Kolf, and H. J. Muller-Eberhard. 1978. The C5b-6 complex: reaction with C7, C8, C9. J. Immunol. 121:484-490.
45. Ramm, L. E., M. B. Whitlow, C. L. Koski, M. L. Shin, and M. M. Mayer. 1983. Elimination of complement channels from the plasma membranes of U937, a nucleated mammalian cell line. J. Immunol. 131:1411-1415.

46. Podack, E. R., W. P. Kolb, and U. J. Muller-Eberhard. 1978. The C5b-6 complex. Formation, isolation and inhibition of its activity by lipoprotein and the S-protein of human serum. J. Immunol. 120: 1841-1848.

47. Fantone, J. C., and P. A. Ward. 1982. Role of oxygen-derived free radicals and metabolites in leukocyte dependent inflammatory reactions. Am. J. Pathol. 107:397-418.

48. Imagawa, D. K., N. E. Osifchin, W. A. Paznekas, M. L. Shin, and M. M. Mayer. 1983. Consequences of cell membrane attack by complement. Release of arachidonate and formation of inflammatory derivatives. Proc. Natl. Acad. Sci. USA. 80:6647-6651.

49. McCord, J. M. 1985. Oxygen-derived free radicals in postischemic tissue injury. New Engl. J. Med. 312:159-163.

50. Klebanoff, S. J. 1982. Oxygen-dependent cytotoxic mechanisms of phagocytes. Adv. Host Def. Mech. 1:111-162.

51. Paller, M. S., J. R. Hoidal, and T. F. Ferris. 1984. Oxygen free radicals in ischemic acute renal failure in the rat. J. Clin. Invest. 74: 1156-1164.

52. Sachs, T., C. F. Moldow, P. R. Craddock, T. K. Bowers, and H. S. Jacob. 1978. Oxygen radicals mediate endothelial cell damage by complement stimulated granulocytes. J. Clin. Invest. 61:1161-1167.

53. Johnson, K. J., and P. A. Ward. 1981. Role of oxygen metabolites in immune complex injury of lung. J. Immunol. 126:2365-2369.

54. Fligiel, S. E. G., P. A. Ward, K. J. Johnson, and G. O. Till. 1984. Evidence for a role of hydroxyl radicals in immune complex induced vasculitis. Am. J. Pathol. 115:375-382.

55. Petrone, W. F., D. K. English, K. Wong, and J. M. McCord. 1980. Free radicals and inflammation. The superoxide dependent activation of a neutrophil chemotactic factor in plasma. Proc. Natl. Acad. Sci. USA. 77:1159-1163.

56. Perez, H. D., and I. M. Goldstein. 1979. Generation of a chemotactic lipid from arachidonic acid by exposure to a superoxide generating system. Fed. Proc. 38:1170. (Abstr.)

57. Carp, H., and A. Janoff. 1979. In vitro suppression of serum elastase inhibitory capacity by reactive oxygen species generated by phagocytosing polymorphonuclear leukocytes. J. Clin. Invest. 63:793797.

58. Matheson, N. R., D. S. Wong, and J. Travis. 1979. Enzymatic inactivation of human alpha-1-proteinase inhibitor by neutrophil myeloperoxidase. Biochem. Biophys. Res. Commun. 88:402-409.

59. Weiss, S. J., G. Peppin, X. Ortiz, C. Ragsdale, and S. T. Test. 1985. Oxidative autoactivation of latent collagenase by human neutrophils. Science (Wash. DC). 227:747-749.

60. Couser, W. G., R. J. Johnson, S. Adler, R. F. Ochi, and S. J. Klebanoff. 1985. A new mechanism of glomerular injury. The myeloperoxidase-hydrogen peroxide-halide system. Kidney Int. 29:271. (Abstr.)

61. Greenwald, R. A., and W. W. Moy. 1979. Inhibition of collagen gelation by action of the superoxide radical. Arthritis Rheum. 22:251259.

62. Greenwald, R. A., and W. W. Moy. 1980. Effect of oxygen-derived free radicals on hyaluronic acid. Arthritis Rheum. 23:455-463.

63. McCord, J. M. 1974. Free radicals and inflammation. Protection of synovial fluid by superoxide dismutase. Science (Wash. DC). 185: 529-531.

64. Bates, E. J., D. A. Lowther, and C. R. J. Handley. 1984. Oxygen free radicals mediate an inhibition of proteoglycan synthesis in cultured articular cartilage. Ann. Rheum. Dis. 43:462-469.

65. Fligiel, S. E. G., E. C. Lee, J. P. McCoy, K. J. Johnson, and J. Varani. 1984. Protein degradation following treatment with hydrogen peroxide. Am. J. Pathol. 115:418-425.

66. Baker, P. J., S. Adler, Y. Yang, and W. G. Couser. 1984. Complement activation by heat-killed human kidney cells. Formation, activity and stabilization of cell bound C3 convertases. J. Immunol. 133:877881 . 